\title{
Pill Dosing Unit
}

National Cancer Institute

\section{Source}

National Cancer Institute. Pill Dosing Unit. NCI Thesaurus. Code C122634.

A dosing unit equal to the amount of active ing redient(s) contained in a pill. 